\title{
Indonesian Democracy as A Model for Egypt after The Arab Spring
}

\author{
Ahmad Sahide ${ }^{1}$, Rezki Satris ${ }^{2}$ \\ ahmadsahideumy@gmail.com,rezki@amikom.ac.id \\ ${ }^{1}$ Hubungan Internasional Program Magister, Universitas Muhammadiyah Yogyakarta \\ 2 Program Studi Hubungan Internasional, Universitas AMIKOM Yogyakarta
} DOI: $10.22219 /$ sospol.v7i2.16222

\begin{abstract}
The Arab Spring in 2011 opened the way for democratization in some Arab countries, including Egypt. Egypt succeeded in overthrowing Hosni Mubarak as the president, but Egypt failed in consolidating democracy after holding a general election in 2012. The main factors of the failure in consolidating democracy in Egypt come from internal and external factors. The internal factor was that Egypt had not been ready for democracy, whereas the external factor was foreign intervention due to national interest. This article analyzes the failure of democratization in Egypt by using Jack Snyder and Georg Sorensen's theory. In the last part of this article, the writer suggested that Egypt should have learned how to consolidate democracy from Indonesia. Indonesia is the best model of democracy for Egypt due to some reasons. The first one is Indonesia and Egypt near a culturally (religious approach), and the second one is Indonesia's success, as the majority Muslim state, in consolidating democracy since 1998.
\end{abstract}

\begin{abstract}
Abstrak
Arab Spring pada 2011 membuka jalan demokratisasi bagi negara-negara Arab, termasuk Mesir. Mesir berhasil menggulingkan Hosni Mubarak sebagai presiden, tetapi gagal dalam mengonsolidasikan demokrasinya setelah pemilihan umum 2012. Ada dua faktor utama di balik kegagalan konsolidasi demokrasi Mesir, yaitu faktor internal dan faktor eksternal. Faktor internalnya adalah bahwa Mesir belum siap untuk berdemokrasi, sementara faktor eksternalnya adalah intervensi asing yang memiliki kepentingan nasional dengan Mesir. Artikel ini menganalisis kegagalan demokratisasi Mesir dengan menggunakan teori Jack Snyder dan George Sorensen. Pada bagian akhir dari artikel ini, penulis berpendapat bahwa Mesir seharusnya belajar dari Indonesia dalam mengonsolidasikan demokrasinya. Indonesia adalah negara yang tepat menjadi contoh bagi Mesir dalam demokratisasi dengan beberapa alasan. Pertama adalah Indonesia dan Mesir mempunyai kedekatan kultural (pendekatan agama) dan yang kedua adalah Indonesia sebagai negara mayoritas Muslim di dunia berhasil mengonsolidasikan demokrasinya sejak 1998.
\end{abstract}

\author{
Keywords \\ The Arab Spring, Egypt, \\ Consolidation of democracy, Failure, \\ Indonesian model
}

\section{Article History}

Received May 31, 2021

Revised October 21, 2021

Accepted November 12, 2021

Published November 17, 2021

\section{Corresponding Author}

Ahmad Sahide, Universitas Muhammadiyah Yogyakarta, Jl. Brawijaya, Geblagan, Bantul, Daerah Istimewa Yogyakarta. 55183.

\section{Introduction}

The Arab Spring is a popular term around the World in January 2011 after. Popular revolts resulted in the fall of several Arab leaders, such as Ben Ali in Tunis, Hosni Mubarak in Egypt, and Moammar Khadafy in Libya. Some of these revolts are still being played out in Yemen and Syria (Zambakari and Kang, 2016: 2). Arabs call this essential political event with alTsaurat al-Arabiyyah, the revolution that will transform the political order from an authoritarian system toward a democratic one. This event became the beginning of genuine popular participation in the political sector to create a more equalitarian, prosperous, inclusive and accessible society. It is so that the West sees the Arab Spring as the turning point where 
authoritarian regimes across the Arab World were toppled and replaced by democracy (Burdah, 2014: 21).

After the socio-political turbulences caused by the initial stages of the Arab Spring, a brand new democratic system was officially established in some Arab countries, where people could express their political opinions and vote. Building the democratic system, based on Jack Snyder's theory, needs a longer time. To build a matured democracy, democratic institutions and a democratic society are needed. Snyder said that to be a mature democracy, at least a state needs to have a twice election, and the election is the only game in town.

That is the social-economic and political environment (democracy) dreamed of by the Arab people, either before or after the Arab Spring happened in 2011. So, after the turbulence of the Arab Spring, democracy becomes an exciting topic of talking to see the future of the Arab World. People begin to be brave in giving their voices about democracy. The political event of 2011 became the event to open the chance for the society to be brave to ask about their political aspiration, mainly the aspiration for the democratic life.

One of the states in Arab Worlds was influenced by the Arab Spring dreaming democracy in Egypt. The mass demonstration in large, or we could call it people power, succeeded to overthrown Hosni Mubarak on February 11, 2011 (Sahide, 2017: 34). One year after popular revolts overthrew Hosni Mubarak, Egypt held free elections, and Muhammad Mursi, leader of the Muslim Brotherhood party, was the elected president, marking the beginning of a new hopeful era in Egypt's history.

However, Egypt's experience with democracy was short-lived. After one year of being inaugurated, President Mursi was toppled by popular revolts and quickly replaced by a military government, marking the end of Egypt's democracy. Egypt, under Mursi's administration, failed in consolidating the democracy dreamed by the people at large. The failure of democracy in Egypt, as well as in Syria, creates doubts that democracy is unsuitable for development in the Islamic world. According to Samuel P. Huntington and Eric Chaney, the Islamic world is experiencing a democratic deficit. However, the author agrees with Esposito that democracy is suitable and can develop in the Islamic world, Indonesia is one example that has succeeded in consolidating its democracy after the 1998 reform (Sahide, 2019: 192). So, Indonesia can be the model of democracy in the Islamic world for Egypt. And the world has recognized Indonesian democracy, Hillary Clinton, former America's Secretary of State, once said, "If you want to know whether Islam, democracy, and women's rights can coexist, go to Indonesia (Hoesterey, 2013: 56). This paper will analyze the failure of Egypt's democracy by using theories from Jack Snyder and Georg Sorensen.

\section{Theoretical Framework}

Democracy has been discussed for about two thousand and five hundred years old, and it is long enough to give a frame of clear idea about democracy which can be agreed by all people, or almost all people in the World (Dahl,2001: 3). Traditionally, democratic states are characterized by applying an openly political system of multiparty and the regime change is done by having a general election for free, the economics of the free market, and the freedom of the press is guaranteed. On the contrary, the nondemocratic states are characterized by having central power from one political party's elite, and the economic system is not open. 
The government controls the media (press). However, by following the time, democracy is not only understood as political freedom, but it also includes the justice concept and social similarities (Dorn, 2014).

Here, the main point is that democracy is a system giving people the chance to participate so the running government can prioritize the universal good (people). So, the system must be transparent, accountable, and give people a chance for public participation, mainly after the Arab Spring. There are two theories of democracy used in this article in analyzing the failure of democracy in Egypt. Those are the theory of democracy from Jack Snyder and the theory of democracy from Georg Sorensen.

a. Democracy from Jack Snyder

In analyzing the failure of democracy in Egypt, the author used the theory of democracy from Jack Snyder. Democracy, according to Jack Snyder, has two crucial stages. Snyder differentiates that democratization consists of mature democracies and democratizing states.

The first stage, from Snyder, is mature democracies, where the democracy gets the stable stage. In a mature democracy, government policy, including foreign policy and military policy, is arranged by the elite (leader) through the fair and justice general election and also subsequent; elite's actions are limited by some constitutional regulations and the civil rights obligation freedom. The second stage is the democratizing states. Snyder defined the second stage as the state that has implemented one or some requirements of the democracy mentioned above. The state remains to have the non-democratic system's vital characteristic (Snyder, 2003:16-17).

Snyder added that one of the crucial aspect for the state to get matured democracy is if the state has implemented general election twice (two turnover rule) as the success indicators of the state in consolidating democracy and the election is the only game in town for changing the leader (Snyder, 2003:17).

b. Democracy from Georg Sorensen

The second theory of democracy used is from Georg Sorensen. Georg Sorensen gave his theory, a little different from Snyder, about the development of democracy. Sorensen said that the transition from non-democracy to democratic rule involves several phases, although ascertaining where one phase begins, another end is brutal. Sorensen added that the new regime would often be a restricted democracy, more democratic than the previous regime but not fully democratic. Several phases of "democratic deepening" may be necessary before this latter stage is reached. Then, the regime still has to be consolidated, when all major political actors see democracy as the "only game in town." There is often considerable overlap between these phases (Sorensen, 2008: 46). In this case, the theory from Sorensen is not far different from Snyder's theory. Snyder used the term 'democratizing state' toward the matured democracy, and Sorensen used the term consolidation and democratic transition. 
The consolidation and democratic transition clearly could be seen in the following chart by Georg Sorensen;

\section{Picture 1: Transition toward democracy}

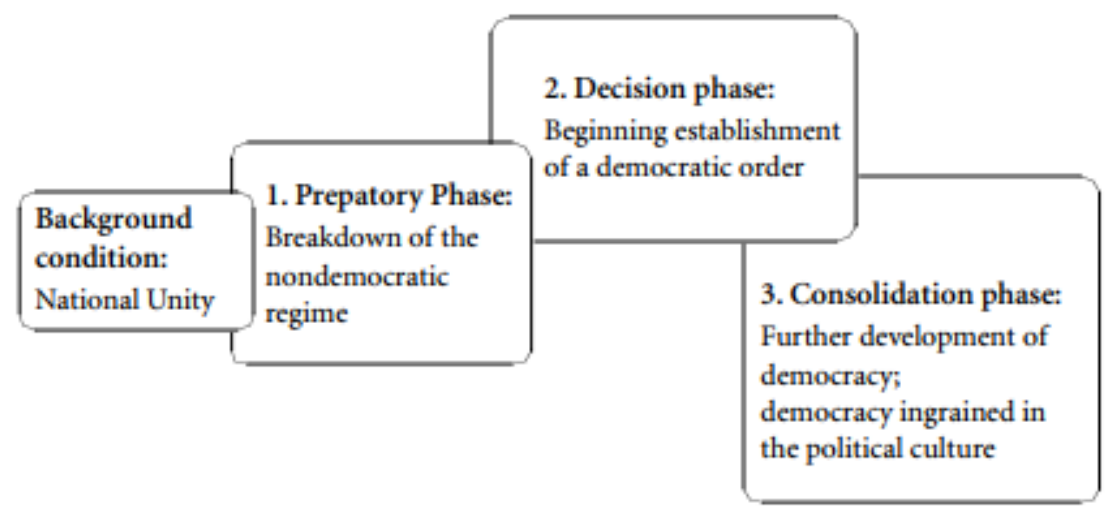

Time

\section{Source: Sorensen, Democracy and Democratization: Processes and Prospects in a Changing} World, 2008.

Both theories of democracy from Snyder and Sorensen will be used in reading and analyzing the failure of democracy in Egypt 2013.

\section{Methods}

This paper focuses on literature review. In this study, the authors read works related to the theme, democracy in Indonesia and the failure of democratization in Egypt after The Arab Spring 2011 with a focus on the development of democracy in Egypt.

Other sources in the form of articles, news, and related recordings or videos serve as supporting data for research to understand further the turmoil of The Arab Spring since 2011 and the failure of Egypt's democratic consolidation in 2013. The existing data is processed by the author using a critical reading approach. Critical reading is one of the post-colonial approaches as an analytical tool. Critical reading is not meant to explain what a text means, but to elaborate it into a new text. In addition, the authors also held several discussion forums to discuss this theme in order to sharpen the analysis and study.

Therefore, this paper tries to look at Indonesia's success in consolidating its postreform democracy as an appropriate model for countries in the Middle East region, especially Egypt. The authors conduct a literature review by following and reading the chronology of the birth of the political turmoil since 2011 to understand the development of issues related to this movement to this day.

\section{Result and Discussion}

a. Egypt before the Arab Spring

On the previously mentioned that the Arab Spring began in Tunisia when a youth 26 years named Mohammed Bouazizi protested against repressive regimes by burning himself. This 
incident also stirred up Tunisia's people's courage to fight the regime Zein Al-Abidin Ben Ali (next to Ben Ali) by conducting demonstrations against the regime in the streets. The power of the people allied to resist Ben Ali's regime is no longer capable of being dammed by force officials belonging to the regime. Ben Ali finally decided to leave the country, and a system of masterfully led him

Egypt includes one of the countries inspired and exposed domino effect regimes from Ben Ali's collapse in Tunisia. As we know that there were joint events of persecution against a young man named Kollena Khaled Sa'eed in June 2010, less than six months before the same event happened, the persecution of Bouazizi, in Tunisia (Korany, 2014: 270 ). In that case, Khaled's oppression could not build the people's power to resist arbitrary regimes.

People power movement since in Egypt after seeing that the people who united against the regime in Tunisia succeeded in overthrowing Ben Ali. Hence, a few days after the world knew the end of the era of Ben Ali, and the Egyptian people came down to the streets, January 25, 2011, demanding the resignation of authoritarian president Hosni Mubarak who was judged to be corrupt and failed to develop for 30 years of his powers (Ketchley, 2017: 2). Besides, the demonstrator demanded reform of government (Jamshidi, 2014: 9). Mubarak's regime was also viewed as a regime violating human rights. Some local and international human rights organizations, such as Amnesty International and Human Rights Watch (HRW), had criticized the violation of human rights in Egypt (Stork: 2012).

It was the situation faced by the Egyptians before the Arab Spring came. So, when the Arab Spring came for them, they hoped the reform for a better life. The government's reform demanded by the demonstrator here means a democracy where the people's rights can be respected. Halim Barakat wrote that the Arab people had demanded democratic life since the 1990s (Barakat, 2012: 373). Arab Human Development Report (AHDR) also had surveyed in 2003, showing that 60 percent of the Arab people supported democracy and 80 percent rejected authoritarian regime (Sau, 2004: 4233). The leaders of the world also took some initiatives. They are the following:

1. The League of Arab States created the Committee on Human Rights in 1968, and it adopted a human rights charter in 1994 (Hassouna, 2001: 51).

2. The conference lasted in Barcelona in 1995, to make a media becoming the center of the relationship between Europe and the Mediterranean states (Middle East), EuroMed relations. The media's name was the Euro-Mediterranean Partnership (EMP), wherein the Euro-Mediterranean Association Agreements systematically put human rights and democracy as an essential element of the agreement (Wouter dan Duquet, 2013: 232-236).

3. In December 2002, the United States of America launched a Middle East Partnership Initiative (MEPI). It was a program to support the political and economical reform; also the empower of the woman. Bush, in his administration, made democratization in the Middle East one of his concerns (Ottaway dan Carothers, 2004: 23).

4. As the United States was hosting the G8 summit in 2004, it sought to broaden support for its political reform initiative for the region by soliciting the support of the other G8 countries (Muasher, 2008: 236).

5. The 44th president of the United States, Barack Obama, when he was in England on May 25, 2011, he made press conference promising that he would make discussion with the G8 
countries related to the support which they could give of the reform movement and democratization lasting in the Middle East (Kompas, 26/05/2011).

However, the Arab people did not have political power in fighting against the regime, so they just kept silent. There was no freedom of speech. It was because the regime was so robust, whereas the people were powerless. There was no civil society that could support the hope for democracy. Bouazizi was a youth becoming the trigger factor of the Arab awakening, including Egypt, to power against the authoritarian regime. It is called the Arab Spring.

b. The Arab Spring and the Hope for Democracy in Egypt

Arab Spring refers to the event happening in the Arab world beginning in Tunisia at the end of 2010. There are many terms of this event. Some call it "Arab Spring," "Jasmine Revolutions," or "Dignity Revolutions." Even though Tariq Ramadhan preferred to use the term "uprisings." Some see the event as the birth of the new era, as a radical turning point between past and future, and boldly speak of revolution (Ramadhan, 2012: 7-8). It was the momentum to end the authoritarian regimes' era not respecting human rights, not giving sovereignty to the people, and treating people following his arbitrary (Jamshidi, 2014: 28). So the new era means the hope for democracy which can give a better life for the people.

The Arab Spring or Jasmine Revolution began in Tunisia on December 17, 2010, when Mohamed Bouazizi, a twenty-six-year-old Tunisian fruit seller from the impoverished city of Sidi Bouzid, set himself on fire. Bouazizi's death lit a spark inside the country in a literal fashion, unleashing decades of frustration toward an autocratic, corrupt, and bloated regime. The protests quickly spread from Sidi Bouzid to another part of Tunisia and soon reached Tunis' capital (Jamshidi, 2014: 8).

The protests also reached Cairo, Egypt. Inspired by the Tunisian mobilization's rapid success, an informal network of Egyptian activists scheduled their demonstrations for the "National Police Day" holiday on January 25, 2011. The January demonstrations attracted more participants across various cities than expected, with thousands filling Egypt's streets. People were coming to the street demanding Mubarak to step down after nearly thirty-one years in power (Jamshidi, 2014: 9).

Mubarak finally left his power on February 11, 2011. After Mubarak left his power, there was a hope that democracy would come soon. It was the end of the authoritarian regime. The initiatives for democratization taken before by some leaders in the World had significant momentum. Egyptians began having power in front of the regime, and they had the same perception that they needed an ideally political system; democracy. Amy C. Alexander dan Christian Welzel said that democracy is inspired by the idea of empowering people to govern their lives (Alexander and Welzel, 2011: 271).

Democracy is believed as one of the solutions from the system in living in a state and nation. It is because democracy gives the people an opportunity to have their sovereignty to guarantee their rights. Nadar Hashemi added that the Arab Spring continues a more prolonged struggle and the Arab-Islamic World's quest for self-determination from external and internal authoritarian forces (Hashemi, 2013: 213). 
Welcoming the momentum of the democracy, Egypt held a general election one year later, 2012. There were two candidates for the president. They were namely Mohammed Mursi and Ahmad Shafik. Mursi was the candidate nominated by Moslem Brotherhood, and Shafik was the Prime Minister of Mubarak's regime. In the presidential election, Mursi won the competition, and he was inaugurated on Saturday, June 30, 2012, in front of the Supreme Court (Zakaria, 2013).

The inauguration for Mursi was viewed as the first step of democratization based on Jack Snider's theory. It was the beginning of democratizing state for Egypt toward a matured democracy. Snyder said democracy could be viewed as matured in a state after having a general election twice. This inauguration became the first step of democratization based on George Sorensen's theory, the first step to building a democratic institution.

Georg Sorensen said that the transition from nondemocratic to democratic rule involves several phases, although ascertaining where one phase begins, and the other ends are brutal. Sorensen introduced the transition toward democracy which can be seen in the following figure (Sorensen, 2008:47).

\section{Picture 2: Democracy phase from Georg Sorensen}

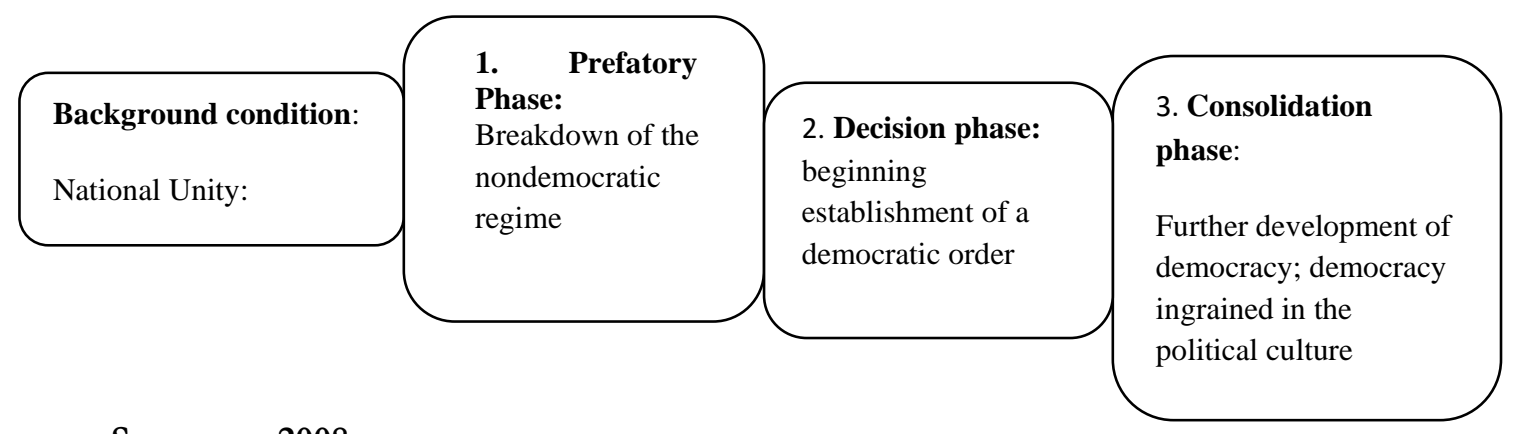

Source: Sorensen, 2008

The end of Mubarak's regime was the first step of democratization in Egypt. It was the prefatory phase, based on the theory of democracy from Sorensen. To have matured democracy, based on Snyder's theory, Egypt must have been in the third stage, the consolidation phase (further development of democracy; democracy ingrained in the political culture).

c. Failure of the Democracy in Egypt

Mohammed Mursi was the President of Egypt, elected democratically. So the victory for Mursi, a figure from Moslem Brotherhood, gave hope that democratization began. The rise of the people's power and the inauguration of Mursi were parts of the consolidating democracy, parts of institutionalizing democracy. Egyptians were stepping into the ideal political system, democracy. However, Mursi failed in consolidating democracy in Egypt. He was toppled down from his position on July 3, 2013, by a military coup (Ketchley, 2017: 3). Reading this situation from Jack Snyder's theory, building democracy in Egypt failed in the first step, democratizing the state. The process did not come to the matured democracy. To have matured democracy, a state, said by Snyder, needs to have an election twice at least, and the election is the only game in town. 
On another side, if we see this political phenomenon from George Sorensen's theory, Egypt just came the first step of democratization, called the prefatory phase. Egypt failed to arrive at the second phase, the decision phase, beginning to establish a democratic order. At the same time, a state must have passed at least three phases to have matured democracy (a term from Snyder), based on Sorensen's theory. It begins from national unity, prefatory phase, decision phase, and consolidating phase.

Some theories explained why the democratization in Egypt failed in the prefatory phase. Moez Guenaien wrote a thesis titled Egypt's Failure To Transition To Democracy Under The Muslim Brotherhood to finish his study at Naval Postgraduate School (2014). Moez Guenaien viewed that two sectors are supporting democratization, mainly in Egypt. Those are from the internal and external sectors. Moez Guenaien said that the most important factor is the internal sector, and he saw that Egypt had not been ready for democracy, so democracy under Mursi failed (Guenaien, 2014).

\section{Internal Sector}

Dr. Mahmud Hamzawi Usman, M.A., Egyptian, is now living in Indonesia and he finished his doctoral program from Universitas Muhammadiyah Yogyakarta (UMY). He said that one of the main factors why democracy failed in Egypt was that by the time Mubarak left his chair as a president, the army had begun to design how to take back the state's control (Usman, 2017). Mahmud Hamzawi Usman added three steps the army took to take back the state's control after the Arab Spring, mainly from Mohammed Mursi. First, the army intentionally made the social and political situation weak where the civil government (Mursi) could not overcome it. Second, the army also made the weak infrastructure, such as turning off the lamp for hours. It had not happened before. Hamza Usman said this situation made people think that the civil government (under Mursi's administration) worst. People were more restive. The third one, Mursi, made a mistake by signing President Decree, which gave him more authority. This one was exploited by the army to issue that Mursi also led the state with authoritarian way.

Figure 1: Internet Freedom Status in Egypt in 2020

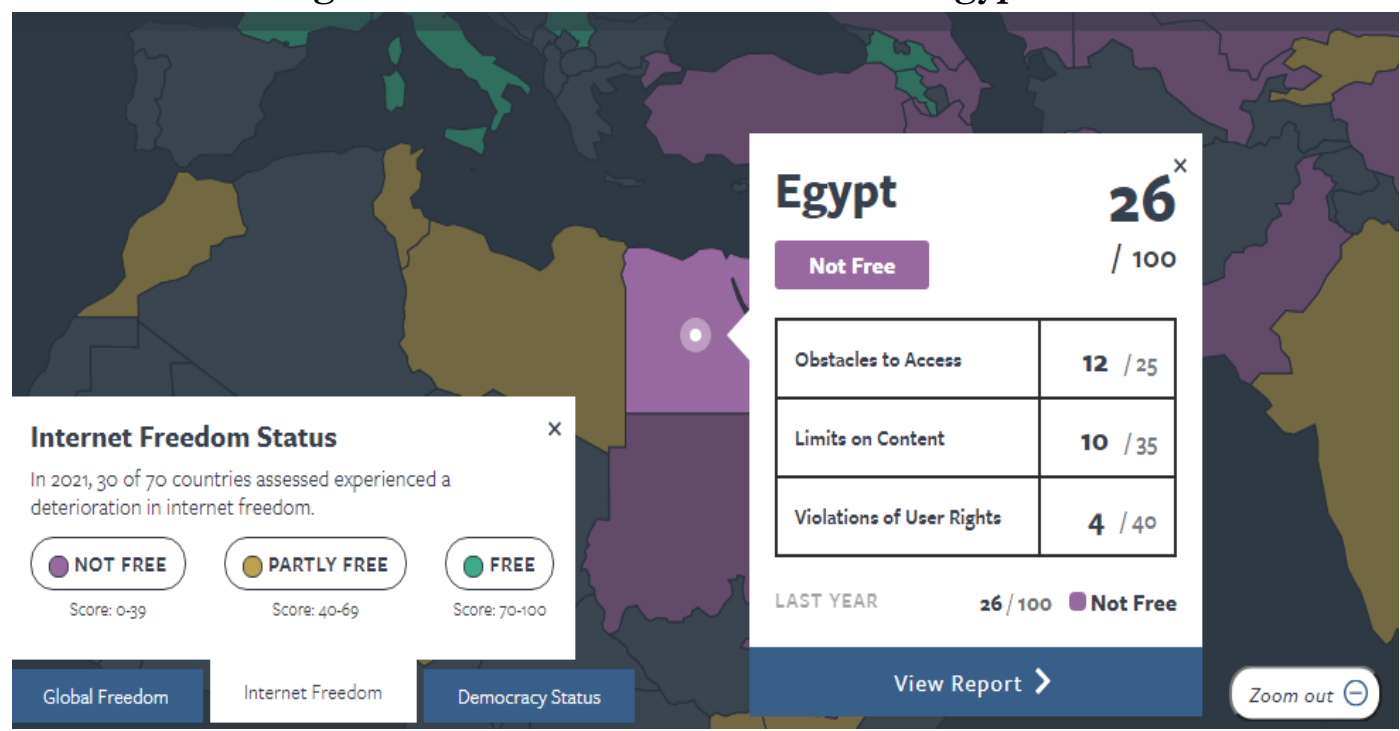

Source: Freedom House (https://freedomhouse.org/explore-the map?type $=$ fotn $\&$ year $=2021 \&$ country $=$ EGY) 
Mohammed Mursi was not aware that he won the presidential election with a different margin. Mursi won the presidential election by having 51,7 percent of the votes. Whereas Ahmad Shafik, his rival, obtained 48,3 percent of the votes (Syukur, 2013: 12). If we saw Ahmad Shafik as the representative of the old order (Mubarak), it means that the power (supporters) of the old order was still strong enough.

In the democratization, from Jack Snyder's theory, there are two opposing insights: famous rivalries and elite persuasion. Both of these explain the correlation between democratization (beginning process) and nationalistic conflict. The first insight assumes that nationalistic rivalry in society existed for a long before democratization begins. Moreover, based on this view, democratization represents a particular group of people who disagree with others' desires. The argument of "old hatred" is one of the firms of the "rivalry among society group" (Snyder, 2003: 22-23).

What happens in Egypt shows that consolidation of democracy brings to nationalist conflict where the enchantment of nationalism is made to obtain people's support. Here is the earlier step of democracy, based on Snyder's theory above. Among the people group competing, people supporting Mursi and supporters of the opposition group (backed up by the military), both use nationalism's enchantment. Moreover, "old hatred" cannot be avoided. The history noted that Moslem Brotherhood nominated Mursi to be the President of Egypt was the group of people prohibited in Mubarak's era. On this side, the general election was just the consensus, not the process of deliberation. Seemingly, it is the show of the political dynamic from the elites in Egypt right now. Mursi failed in consolidating people's consensus bringing him to be the number one person in the biggest (powerful) state of the Arab States. Finally, Mursi was toppled down by the people's power supported by the military and the foreign sectors.

\section{External sectors}

Some data showed the foreign intervention of overthrowing Mursi in 2013, mainly the United States of America (USA). Ellis Goldberg wrote that the West might be worried that the crisis (Arab Spring) would bring democracy too quickly to Egypt and empower Moslem Brotherhood (Goldberg, 2011: 110). What was written by Ellis Goldberg is right. In the general election in 2012, Mohammed Mursi from Moslem Brotherhood won the election. Moreover, Mursi signaled that the United States would lose its essential political ally in the Middle East. In August 2012, Mursi visited China before continuing his state journey to Iran in attending the High Conference of Non-Block Movement. It was noted that China was the third state visited by Mursi after Saudi Arabia and Utopia, not the United States (Kompas, 30/08/2012).

Those visiting can be read that Mursi would try to change the Egypt orientation from the West (USA) to the East. It must have been bad news for the USA. So, in the coup of overthrowing Mursi, 2013, some data showed the USA's involvement in funding the group of people moving to overthrow Mursi (Agastya, 2013: 81). Prof. Dr. Sangidu, M.Hum, the Indonesian diplomat in Egypt, said that one of the group people sponsored by the USA and Israel was a 'black box'.

The failure of Egypt's democratization is not because Egypt has not been ready for democracy, such as Moez Guenaien above. Democratization in Egypt failed because the USA supported the group of people moving to make that process fail. Tunisia's democratization has 
been running well for one decade because there is no foreign intervention, such as in Egypt. Data from the Global Freedom Status released by Freedom House in 2020 places Tunisia as a free country, the same as Western countries in general. The Western media then labeled Tunisia a "success story" (Guesmi, 2020). Egypt needs to learn from the majority of Muslim states which succeed in implementing democracy. When the Arab Spring happened, three majority Muslim states could succeed in implementing democracy, such as Turkey, Iran (with different characteristics), and Indonesia.

\section{Learn from Indonesian Model}

It has been explored above that democracy became the hope of the Arabian people after the Arab Spring 2011. Democracy has been the dream of the Arabian in general, which we can see from the survey result released by the Arab Human Development Report (AHDR) in 2003 showed that 60 percent of the Arab people supported democracy and 80 percent of them rejected authoritarian regimes (Sau, 2004: 4233). The political event of 2011 opened a chance more to build democratically political order in the Arab states, including Egypt and some other countries. Initiatives also had been taken for the political reform needed by the Arab states to build the ethic of the good government (Sahide, 2017: 13).

However, there have been debates and an extensive discussion on whether Islam is compatible with democracy concerning the Middle East. Some scholars do not have an optimistic stance on that matter and have argued that Islam is not compatible with democracy. In contrast to this argument, there has been a tendency to maintain that Islam and democracy are incompatible (Baskan, 2005: 849). The pessimistic scholars are such as Samuel P. Huntington, Eric Chaney, and Alfred Stepan. For example, Eric Chaney and his friends gave 'deficit democracy' term in the Arab World (Chaney, Akerlof, and Blaydess, 2012). Optimistic scholars included Julie Chernov Hwang, John L. Esposito, Tariq Ramadan, and Hussein A. Hassouna. Esposito saw that democracy had been an integral part of modern Islamic political thought and practice (Esposito, 1996: 218).

Indonesia is one example where Islam and democracy can coexist after people's power successfully overthrown Soeharto from the presidency in 1998. Even Tunisia, the only state in the Arab World that succeeded in consolidating democracy, came to resemble Indonesia's major Islamic groups in arguing that democracy was not only acceptable but necessary (Stepan and Linz, 2013: 23). Since 1998, Indonesia has succeeded in consolidating democracy. The success of consolidating democracy was recognized by Hillary Clinton, presidential candidate of the United States in 2016. Hillary said that: "If you want to know whether Islam, democracy, modernity, and women's rights can coexist, go to Indonesia." Hillary Clinton and Madeleine Albright praised Indonesia's democratization as the ideal model for the Arab Spring (Hoesterey, 2013: 56). Indonesia is proof that the thesis from pessimistic scholars such as Huntington is wrong.

Indonesia has experience led by the authoritarian leader (undemocratic system) under the New Order of Soeharto, from 1966 to 1998. Indonesia and Egypt had a similarity, authoritarian regimes controlled by the military. However, the people power movement in Indonesia in 1998 succeeded in overthrowing Soeharto from his power as the President of Indonesia. However, it was called reformation, not revolution. 
After the reformation, Indonesia was led by civil, and the military went back to barracks. Military left the political practice. It was the beginning of the consolidation of democracy in Indonesia. Based on Jack Snyder's theory about the consolidation of the democracy of Indonesia, Indonesia has been in a matured democracy. There have been five general elections held after 1998. Those are in 1999, 2004, 2009, 2014, and 2019. Furthermore, Indonesia has been in the Consolidation Phase, based on Sorensen's theory. It indicates that Indonesia succeeds in consolidating democracy until getting mature democracy (Snyder) or democracy has been ingrained in the political culture (Sorensen). Therefore, Hillary Clinton appreciated democracy in Indonesia by saying that Islam, democracy, modernity, and women's rights can coexist in Indonesia.

Egypt should have learned the success of consolidating and getting matured democracy of Indonesia after the Arab Spring 2011. When Mubarak stepped down in 2011, Indonesia's diplomats were eager to share Indonesia's story in consolidating democracy with their Egyptian friends and diplomats. The initiatives were taken, such as Indonesia's Institute for Peace and Democracy (IPD) convened Egyptian and Indonesian academics, government officials, and civil society leaders from May 25-27, 2011 for the "Egypt-Indonesia Dialogue on Democratic Transitions." Over the next eighteen months, IPD sponsored four additional workshops: "Building Electoral Democracy in Egypt: Lessons Learned from the Indonesian Experience" (July 25, 2011, in Cairo);7 "Empowering the Electoral Management Body" (October 20-22, 2011 in Indonesia); "Islam, the State, and Politics" (April 11-12, 2012 in Jakarta);8 and, "Constitutional Reform and Constitution Building" (November 5-7, 2012 in Bali) (Hoesterey, 2013: 58). Those are the actual initiatives in transferring Indonesia's experience in consolidating democracy after 1998.

\section{Why should Indonesia be?}

There are some reasons why Egypt must learn from Indonesia's experience in consolidating democracy. Firstly, Egypt is the majority Muslim state of the 86,7 million population (2014), where the Sunni sect is about 90 percent. Like Egypt, Indonesia is the majority Muslim state which Sunni is the majority. It makes two states near culturally, and it will be one of the essential things in transforming the values of democracy from Indonesia to Egypt. There is no cultural hindrance (Sahide, 2019: 193).

Secondly, Indonesia is only one of the most prominent Muslim states globally, succeeding in implementing democracy and being recognized globally. Turkey claims to have implemented democracy, but the failed coup in 2016 brought the state to the authoritarian system. Turkey has been backslid into authoritarianism under Recep Tayyip Erdogan's administration (Menchik, 2019: 1). Erdogan repressed the freedom of the people. So, speaking of democracy, Turkey cannot be the model for Egypt in building a democratic system. On another side, Mustafa Kemal Ataturk built the republic of modern Turkey in a secular way that is difficult to imitate Egypt. Turkey's secularization was an elite political project and not internal to the religious community (Gülalp, 2005: 356). When the Arab Spring impacted Egypt in 2011, there was no secularization project taken by the elite, such as in Turkey by Ataturk.

Iran also claims to have implemented democracy, and Iran routinely holds a general election every four years. The general election has been the only game in that state to elect the 
national leader (President). However, democracy in Iran is not recognized by the West due to the influence of Syria's doctrine, where the Imam (Wilayat al-Faqih) has the dominant power. In Iran, Wilayat al-Faqih has more significant power than the president, and in Syria's tradition Imam (ulama) is mashed (wholly), one who never makes any mistakes. Putting Imam as the whole man and not critiqued is the deficit of democracy. Therefore, seen from the political rights and civil liberties rankings for the Middle East and North Africa (MENA) countries, Iran includes the "Not Free" state (Harrigan and El-Said, 2011: 32).

Those are the reasons why Indonesia should be a model of democracy for Egypt. Indonesia has implemented democracy for about twenty years. Based on Jack Snyder Theory, Indonesia has been in a "matured democracy" stage, or democracy has been ingrained in Indonesia's political culture (Sorensen's theory). According to Polity and most scholar' indicators from Polity, Indonesia has remained a largely successful democracy (Menchik, 2019: 1). Indonesia is the only one of the World's Muslim states succeeding in implementing democracy and being recognized.

Those are why Egypt should learn from Indonesia in consolidating democracy after the Breakdown of the nondemocratic regime. Egypt should learn from Indonesia about civil society's role, mainly the Indonesian Islamic organization, supporting democracy.

\section{Critical Success of Consolidating Democracy}

The two most prominent Indonesian Islamic organizations in Indonesia become the foundation of democracy: Muhammadiyah and Nahdatul Ulama. Muhammadiyah and Nahdatul Ulama can be a 'state in a state,' but it does not break the relationship with the state (Indonesian Government) even though they are separated from the government. The state and Indonesian Islamic organizations in Indonesia are synergized in building a democratic system. Indonesian Islamic organizations are not the enemy of the state. That is not found in Egypt, where the state and the Egyptian Islamic organization are opposed.

The Indonesian Islamic organizations, such as Nahdatul Ulama and Muhammadiyah, as the critical success of the democratic consolidation is recognized by Jeremy Menchik from Boston University. Menchik writes that since Indonesia's democratic transition and consolidation in the twenty years, scholars have pointed to mass Islamic organizations as a crucial reason for the country's relative success. While other Muslim-majority democracies - including Egypt, Turkey, Senegal, Pakistan and Nigeria - have backslid into authoritarianism (Menchik, 2019: 1).

Civil society is the foundation of democracy where Muhammadiyah and Nahdatul Ulama are the giants of Indonesian Islamic civil society, as "contingent democrats" (Menchik, 2019: 1). William Shepard categorizes Muhammadiyah as a group of "Islamic-Modernism" whose movement is focussing more on developing "Islamic society" than "Islamic state" (Nashir, 2016: 5). Muhammadiyah develops the Islamic doctrine commit to the state and nation (Bahtiar, 2017). Nahdatul Ulama does the same thing with Muhammadiyah, even though having a different color. That is why Azyumardi Azra asserts that Indonesia Islam is Islam with a smiling face, full of peace and moderate, so there is no problem with plurality, democracy, human rights and other tendencies in the modern World (Muhsin, Rochmawati, dan Huda, 2019). Muhammadiyah and Nahdatul Ulama have an essential role in making Islam's face, such as Azyumardi Azra, from Islamic State University of Syarif Hidayatullah Jakarta. 
These Islamic mass organizations build the doctrine that nationalism is a good Muslim and receiving democracy as the state's system. So, Muhammadiyah and Nahdatul Ulama are the critical success of the democratic consolidation in Indonesia after the New Order era of Soeharto. Muslim Brotherhood does not take this role in Egypt. Muslim Brotherhood can not take the role as the critical success of democracy because the Moslem Brotherhood movement focuses on building an "Islamic state", not "Islamic society".

\section{Conclusion}

Democracy in Egypt failed, democratizing the state when the people's power overthrew Mursi. The failure of democratization in Egypt is due to the internal and external sectors. The internal sectors were that Egypt had not been ready for democracy because of the lack of civil society, the military didn't want to hand over power to civilian groups. At the same time, the foreign sector (intervention) was the role of the United States behind the overthrowing of Mursi from the presidency. Egypt did not follow the Indonesian way in the success of the consolidation of the democracy. Whereas Indonesia can be the suitable model for Egypt in building a democratic system, some similarities belong to both states. Unfortunately, Indonesia does not have a solid diplomatic role in the Middle East, mainly in Egypt, so the ideal model of democracy in Indonesia's Islamic state cannot be transformed.

The Indonesian government's homework is how to build a strong relationship in Middle Eastern countries. Indonesia has a chance if seen from Egypt President Abdel Fattah el-Sisi's official visit in September 2015. In March 2017, King Salman ibn Saud visited Indonesia and began to invest. El-Sisi and King Salman's visit indicated that Indonesia is an important actor in global politics. It will lead to a significant role in the Middle Eastern countries, including transforming the model of the Indonesian democracy. Therefore, this article can open a discourse for practical action by the Indonesian Ministry of Foreign Affairs to strengthen Indonesia's role in the Middle East region in transforming the Indonesian model of democracy.

\section{References}

Amar, Paul. (2013). Dispatches from the Arab Spring. University of Minnesota Press.

Bahtiar, Asep Purnama. 2017. Komitmen Muhammadiyah dalam Konteks Kebangsaan dan Good Governance. Tajdida: Jurnal Pemikiran dan Gerakan Muhammadiyah, Vol. 15. No.2. 2017.

Baskan, Filiz. (2005). The Fethullah Gülen Community: Contribution or Barrier to the Consolidation of Democracy in Turkey? Source: Middle Eastern Studies, Vol. 41, No. 6 (Nov. 2005), pp. 849861. Published by: Taylor \& Francis, Ltd.

Brennan, Christopher L. (2015). Fall of the Arab Spring from Revolution to Destruction. San Diego: Progressive Press.com.

Burdah, Ibnu. (2014). Islam Kontemporer, Revolusi dan Demokrasi. Malang: Intrans Publishing.

Dahl, Robert. 2001. Peribal Demokrasi. Menjelajahi Teori dan Praktek Demokrasi Secara Singkat. Jakarta: Yayasan Obor Indonesia.

Diamond, Larry. (2013). Why Wait for Democracy? Source: The Wilson Quarterly (1976-), Vol. 37,

No. 1, Is Democracy Worth It? (Winter 2013). Published by: Wilson Quarterly.

Dorn, James A. (2014). Equality, Justice, and Freedom: A Constitutional Perspective. Libertarianism.org. 
Eric Chaney, George A. Akerlof and Lisa Blaydess. Democratic Change in the Arab World, Past and Present [with Comments and Discussion]. Source: Brookings Papers on Economic Activity, (SPRING 2012), pp. 363-414. Published by: Brookings Institution Press.

Esposito, John L. (1996). Ancaman Islam, Mitos Atau Realitas? Terj. Alwiyah Abdurrahman dan MISSI. Bandung: Mizan.

Freedom House. 2021. Internet Freedom Status. https://freedomhouse.org/explore-themap?type $=$ fotn\&year $=2021 \&$ country $=E G Y$

Guenaien, Moez. (2014). Egypt's Failure to Transition to Democracy Under The Muslim Brotherhood. California: Naval Postgraduate School.

Guesmi Haythem. 2020. How the West hollowed out the Tunisian revolution. Aljazeera, edisi 17 Desember 2020. https://www.aljazeera.com/opinions/2020/12/17/western-media-andacademia-hollowed-out-the-tunisian-revolution

Gulalp, Haldun. (2005). Enlightenment by Fiat: Secularization and Democracy in Turkey. Source: Middle Eastern Studies, Vol. 41, No. 3 (May 2005), pp. 351-372. Published by: Taylor \& Francis, Ltd.

Harrigan, Jane and Hamed El-Said (ed). (2011). Globalisation, Democratisation and Radicalisation in the Arab World. New York: Palgrave Macmillan.

Hoesterey, James B. (2013). Is Indonesia a Model for the Arab Spring? Islam, Democracy, and Diplomacy. Source: Review of Middle East Studies, Vol. 47, No. 1 (Summer 2013), pp. 56-62. Published by: Middle East Studies Association of North America (MESA).

Ketchley, Neil. 2017. Egypt in a Time of Revolution. Contentious Politics and the Arab Spring. United Kingdom: Cambridge University Press

Korany, Bahgat. (2014). A Microcosm of the Arab Spring, Sociology of The Tabrir Square. In Beyond The Arab Spring, edited by Mehran Kamrava. New York: Oxford University Press.

McMillan, M.E. (2016). From the First World War to the Arab Spring, What is Going On in the Middle East? New York: Palgrave Macmillan.

Menchik, Jeremy. 2019. Moderate Muslims and Democratic Breakdown in Indonesia. Asian Studies Review, DOI: 10.1080/10357823.2019.1627286.

Moleong Lexy J. (2010). Metodologi Penelitian Kualitatif. Revised edition. Bandung: PT. Remaj Rosdakarya.

Muhsin, Ilya, Nikmah Rochmawati, dan Muhammad Chairul Huda. 2019. REVOLUTION OF ISLAMIC PROSELYTIZING ORGANIZATION: From Islamism to Moderate. Qudus International Journal of Islamic Studies. Volume 7, Number 1, 2019. DOI: 10.21043/Fijis.v7i1.5076

Nashir, Haedar. 2016. Muhammadiyah: Gerakan Modernisme Islam. Tajdida: Jurnal Pemikiran dan Gerakan Muhammadiyah, Vol.14. No.1. 2016.

Rutherford, Bruce K.. (2013). Egypt: navigating an uncertain transition. Published by Foreign Policy Association is collaborating with JSTOR to digitize, preserve and extend access to Great Decisions.

Sabri, Ciftci. (2013). Secular-Islamist Cleavage, Values, and Support for Democracy and Shari'a in the Arab World. Source: Political Research Quarterly, Vol. 66, No. 4 (DECEMBER 2013), pp. 781 793. Published by: Sage Publications, Inc. on behalf of the University of Utah. 
Sahide, Ahmad. (2017). Gejolak Politik Timur Tengah (Dinamika, Konflik, dan Harapan). Yogyakarta: The Phinisi Press.

Sahide, Ahmad. (2017). The Arab Spring and Democratiation; Why is Syria Different? Jurnal Sospol, Vol 3 No 2 (Juli-Desember 2017).

Sahide, Ahmad. (2019). The Arab Spring; Tantangan dan Harapan Demokratisasi. Jakarta: Kompas.

Sau, Ranjit. (2004). Democracy and Reform: Voices in West Asia. Sumber: Economic and Political Weekly, Vol. 39, No. 38 (Sep. 18-24, 2004), pp. 4232-4234.

Snyder, Jack. (2003). Dari Pemungutan Suara ke Pertumpahan Darah. Terj. Martin Aleida dan

Parakitri T. Simbolon. Jakarta: Kepustakaan Populer Gramedia

Sorensen, Georg. (2008). Democracy and Democratization, Processes and Prospects in a Changing World. Denmark: Westview Press.

Stepan, Alfred and Juan J. Linz. 2013. Democratization Theory And the "Arab Spring". Journal of Democracy, Volume 24, Number 2.

Stork, Joe. (2012). Mubarak Convicted, but Abuses Continue in Egypt. Human Roght Watch, June 10, 2020. https://www.hrw.org/news/2012/06/10/mubarak-convicted-abuses-continueegypt.

Usman, Mahmud Hamzawi. (2017). Politik Mesir Dewasa Ini. Diskusi Pakar yang diselenggarakan oleh Pascasarjana UMY, 24 Februari 2017.

Zakaria, Patty. 2013. Emerging Illiberal Democracy: Egypt in the Wake of Arab Spring. AtlanticCommunity.Org. The Open Think Thank on Foreign Policy.

Zambakari, Christopher, and Tarnjeet K. Kang. 2016. The Arab Spring and the Struggle for Democracy in Egypt. Public Policy Review, Spring Edition. Volume 21, Number 1. 